Cakrawala Dini: Jurnal Pendidikan Anak Usia Dini | p-ISSN 2087-I317 | e-ISSN 2621-8321

Vol. II. No.2 November 2020 | Hal 134-140

\title{
MODEL PEMBELAJARAN INTERACTIVE STORYTELLING BERBASIS APLIKASI ANDROID UNTUK MEMFASILITASI KETERAMPILAN MENYIMAK ANAK USIA DINI
}

\author{
Istikhoroh Nurzaman ${ }^{1}$, Gilar Gandana ${ }^{2}$, Annisa Shofaril Wahidah ${ }^{3}$ \\ 1,2,3 Universitas Pendidikan Indonesia
}

\begin{abstract}
This research is motivated by the results of previous studies that interactive storytelling programs can improve one of children's language skills, namely speaking skills. The next problem is the problem of teachers being able to use Android but they don't facilitate their Android to be implemented in storytelling learning. This has an impact on the lack of ability to listen to children in storytelling activities. Therefore further research is conducted to develop interactive storytelling models based on Android applications that can facilitate early childhood listening skills. This is considered necessary because it is based on one of UPI's research umbrella, namely the application of technology in learning. It is intended to sustain and or strengthen UPI's identity as a professional educational institution for teachers and other professional educators. The research method used in this study is the McKenney \& Reaves Educational Design Research (EDR) model. Data collection techniques used were interviews, observation, audio and visual, and validation from experts. The instrument was validated by early childhood learning model experts and linguists and through several revisions as the expert judgement advice. After the internal validation has been carried out, this research will then go through an external validation phase conducted during two trials at TK Perwari I. In general, the interactive storytelling model based on the Android application is feasible to use and produce interactive storytelling models based on the Android application to facilitate listening skills of children. early age.
\end{abstract}

Keyword: interactive storytelling model, android application, listening skills.

\begin{abstract}
Abstrak: Penelitian ini dilatar belakangi oleh hasil penelitian sebelumnya bahwa interactive storytelling program dapat meningkatkan salah satu kemampuan berbahasa anak yakni keterampilan berbicara Permasalahan berikutnya adalah permasalahan guru mampu menggunakan android tetapi mereka tidak memfasilitasi android mereka untuk diimplementasikan pada pembelajaran bercerita. Hal ini berdampak pada kurangnya kemampuan menyimak anak pada kegiatan bercerita. Karena itu dilakukan penelitian lanjut untuk mengembangkan model interactive storytelling berbasis aplikasi android yang dapat memfasilitasi keterampilan menyimak anak usia dini. Hal ini dianggap perlu karena berlandas kepada salah satu payung penelitian UPI yaitu penerapan teknologi dalam pembelajaran. Hal ini ditujukan untuk menopang dan atau memperkokoh jati diri UPI sebagai lembaga pendidikan profesional guru dan pendidik profesi lainnya. Metode penelitian yang digunakan dalam penelitian ini adalah Educational Design Research (EDR) model McKenney\& Reaves. Teknik pengumpulan data yang digunakan yaitu wawancara, observasi, audio dan visual, serta validasi dari ahli. Instrumen divalidasi oleh ahli model pembelajaran anak usia dini dan ahli bahasa dan melalui beberapa revisi sesuai saran validator. Setelah validasi internal dilakukan, selanjutnya penelitian ini melalui tahap validasi eksternal yang dilakukan selama dua kali uji coba di TK Perwari I. Secara umum, model interactive storytelling berbasis aplikasi android ini layak digunakan dan menghasilkan produk model interactive storytelling berbasis aplikasi android untuk memfasilitasi keterampilan menyimak anak usia dini.
\end{abstract}

Kata Kunci: Model interactive storytelling, aplikasi android, keterampilan menyimak.

\footnotetext{
'Universitas Pendidikan Indonesia, Email: isti国upi.edu

${ }^{2}$ Universitas Pendidikan Indonesia, Email: gilargandana23国gmail.com

${ }^{3}$ Universitas Pendidikan Indanesia, Email: shafarilannisa国gmail.com
} 


\section{PENDAHULUAN}

Pendidikan Anak Usia Dini (PAUD) merupakan pendidikan yang diberikan kepada anak usia dini 0-6 tahun dalam rangka meningkatkan pertumbuhan dan perkembangan anak. Pendidikan anak usia dini adalah suatu upaya pembinaan yang ditujukan kepada anak sejak lahir sampai dengan usia enam tahun yang dilakukan melalui pemberian rangsangan pendidikan untuk membantu pertumbuhan dan perkembangan jasmani dan rohani agar anak memiliki kesiapan dalam memasuki pendidikan lebih lanjut (Undang Undang Nomor 20 Tahun 2003 Pasal 1 Butir 14). Pendidikan anak usia dini terdiri dari enam aspek perkembangan anak usia dini yang harus dikembangkan secara optimal. Aspek perkembangan tersebut meliputi aspek nilai agama dan moral, aspek sosio emosional, aspek kognitif, aspek fisik motorik, dan aspek bahasa.

Bahasa merupakan alat komunikasi yang sangat penting dalam kehidupan manusia, karena berfungsi sebagai alat untuk menyatakan pikiran, gagasan dan perasaan kepada orang lain. Berbagai penelitian yang telah dilakukan bahwa usia dini merupakan masa peka yang sangat penting bagi pendidikan anak. Maka perlu diberikan stimulus yang tepat agar keterampilan anak berkembang secara optimal, termasuk kemampuan berbahasa. Menyimak merupakan salah satu keterampilan berbahasa yang mendasar dan yang pertama kali dipelajari oleh manusia dalam hidupnya.

"Menyimak adalah suatu proses kegiatan mendengarkan lambang lambang lisan dengan penuh perhatian, pemahaman, apresiasi, serta implementasi untuk memperoleh informasi, menangkap isi atau pesan serta memahami makna komunikasi yang telah disampaikan oleh sang pembicara melalui ujaran atau bahasa lisan" (Tarigan, 2014, hlm. 19). Dari pernyataan tesebut terlihat bahwa keterampilan menyimak perlu mendapat perhatian serius karena kemampuan menyimak merupakan kemampuan dasar dalam keterampilan berbahasa yang harus dimiliki setiap anak. Empat keterampilan bahasa yang menjadi tingkatan bagi anak yaitu menyimak, berbicara, membaca, menulis. Kemampuan menyimak ini memiliki tugas pencapaian perkembangan bagi anak usia 5-6 tahun sebagaimana yang tertulis dalam Permendikbud Nomor 146 Tahun 2014 tentang Kurikulum 2013 PAUD bahwa pada kompetensi dasar anak harus mampu memahami bahasa reseptif (menyimak dan membaca) dan menunjukkan kemampuan berbahasa reseptif (menyimak dan membaca) (Mendikbud RI, 2014, hlm. 30-31).

Penelitian yang dilakukan penulis pada tahun 2018 tentang penggunaan metode interaktif pada keteramplilan bahasa anak usia dini menunjukkan bahwa mampu meningkatkan keterampilan berbahasa anak usia dini (Nurzaman., dkk, 2018). Eksperimen berdasarkan periodisasi waktu menunjukkan pengaruh positif secara signifikan terhadap keterampilan berbicara subjek penelitiannya, pada penelitian sebelumnya juga menunjukkan bahwa perlu adanya pengembangan komponen pada model pembelajaran yang disesuaikan melaui pendekatan, strategi, metode, dan teknik supaya selaras dengan kondisi ruang pembelajaran dan selaras dengan menghadapi transisi menuju revolusi industri 4.0. Teknik yang digunakan berbasis aplikasi android, karena permasalahan yang didapatkan berikutnya adalah permasalahan guru mampu menggunakan android tetapi mereka tidak memfasilitasi android mereka untuk diimplementasikan pada pembelajaran bercerita Hal tersebut berlandaskan bahwa salah satu keterampilan guru pada abad 21 adalah mampu menguasai dan mempraktekan 
teknologi dalam pembelajaran di kelas. (Gunawan., dkk, 2019).

Selaras dengan pernyataan (Schwab, dalam Cahyono 2018, Yasbiati dkk 2019, dan Lestari dkk 2019) bahwa dunia tengah menghadapi transisi menuju revolusi industri 4.0 Hal ini ditandai dengan tergabungnya dunia fisik, digital, dan biologishal tersebut menunjukkan bahwa akan ada perubahan ke arah lebih baik, bersamaan dengan berpadunya dunia fisik, digital dan biologis. Oleh sebab itu subjek pendidikan akan semakin berkualitas apabila objek pendidikannya berkualitas.

BerdasarkanSurat Keputusan

Rektor UPI Nomor 0651/H40/PR/2011 tanggal 1 Februari 2011 pada Renstra UPI, tentang payung penelitian UPI sebagai arah kebijakan dan rujukan dalam usulan dan implementasi kegiatan penelitian di lingkungan UPI, bahwa salah satu payung penelitian universitas ditujukan untuk menopang dan atau memperkokoh jati diri UPI sebagai lembaga pendidikan profesional guru dan pendidik profesi lainnya, yaitu penerapan teknologi dalam pembelajaran.

Ditinjau dari latar belakang tersebut, selanjutnya akan lebih berarti bila dilakukan analisis terhadap pola dan hubungan dari setiap komponen pembelejaran yang tepat diterapkan berbasis teknologi guna penyelarasan dari revolusi industri dan peraturan rektor tentang penerapan teknologi dalam pembelajaran. Penggunaan aplikasi android pada pembelajaran bercerita pada anak usia dini merupakan hal yang baru terutama bagi guru anak usia 5-6 tahun tempat penelitian dilaksanakan. Dengan demikian judul penelitian ini adalah "Model Interactive Storytelling Berbasis Aplikasi Android untuk Memfasilitasi Keterampilan Menyimak Anak Usia Dini”.

\section{METODOLOGI PENELITIAN}

Secara umum, penelitian ini dilakukan untuk mengembangkan model interactive storytelling berbasis aplikasi android sebagai salah satu solusi bagi permasalahn yang dialami guru yang berupa panduan dalam melaksanakan kegiatan bercerita. Oleh karenanya, penelitian ini menggunakan metode Educational Design Research (EDR). EDR merupakan sebuah pendekatan penelitian dengan menggunakan analisis data kuantitatif dan kualitatif (Herrington, Mckenney, Reeves, \& Oliver, 2007). Jan Van Den Akker, Koeno Gravemeijer, dkk (2006, hlm. 1) juga berpendapat bahwa Educational Design Research yaitu "Studi sistematis merancang, mengembangkan dan mengevaluasi program pendidikan, proses, produk". Sedangkan menurut Plomp (2010), Educational Design Research adalah:

Suatu kajian sistematis tentang merancang, mengembangkan dan mengevaluasi intervensi pendidikan (seperti program, strategi dan bahan pembelajaran, produk dan sistem) sebagai solusi untuk memecahkan masalah yang kompleks dalam praktik pendidikan, yang juga bertujuan untuk memajukan pengetahuan kita tentang karakteristik dari intervensi-intervensi tersebut serta proses perancangan dan pengembangannya (Plomp, 2010).

Pada pengembangan proses penelitian ini, peneliti menggunakan model pengembangan EDR versi McKenney \& Reaves. Adapun model generik EDR tersebut adalah sebagai berikut ini:

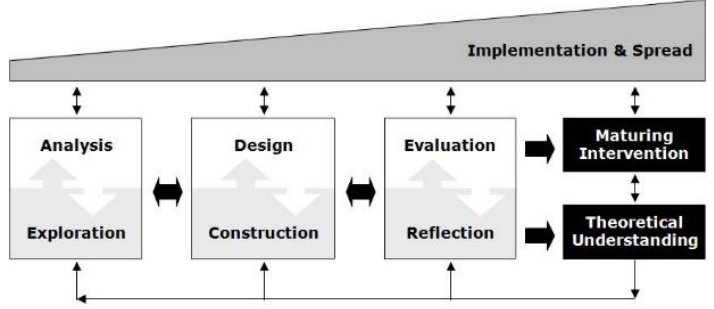

Gambar 3.1 Model Generik EDR (McKenney \& Reaves, 2012)

Teknik pengumpulan data menggunakan wawancara, observasi, 
audio dan visual, serta expert judgement. Penganalisisan data pada penelitian ini, peneliti menggunakan analisis data model Miles dan Huberman. Miles dan Huberman (dalam Sugiyono, 2017, hlm. 337) menyatakan bahwa "Aktivitas dalam analisis data kuaJitatif dilakukan secara interaktif dan berlangsung secara terus menerus sampai tuntas, sehingga datanya sudah jenuh". Adapun komponen analisis data berdasarkan model Miles dan Huberman terdiri dari reduksi data, penyajian data, dan penarikan kesimpulan/verifikasi. "We see analysis are three concurrent flows of activity: (1) data condensation, (2) data display, (3) conclusion drawing/verification" (Miles dan Huberman, 2014)

\section{HASIL PENELITIAN DAN PEMBAHASAN}

A. Analysis and Exploration

Kebutuhan akan panduan bercerita yang interaktif berbasiskan teknologi android di lapangan sangat dibutuhkan, terutama untuk memfasilitasi kemampuan bahasa anak. Sebagaimana pada hasil studi pendahuluan yang telah dilakukan oleh peneliti di TK Perwari I pada kelompok B bahwa guru belum bisa menyampaikan cerita dengan menarik karena masih kurangnya persiapan dalam melaksanakan bercerita dan anak-anak belum dapat menyimak dengan baik. Hal ini dibuktikan saat anak diminta untuk menceritakan kembali atas cerita yang telah disampaikan, anak belum bisa melaksanakan intruksinya. Sedangkan anak pada usia 5-6 tahun diharapkan dapat mencapai kemampuan menyimak sesuai indikator yang telah dituliskan dalam Permendikbud Nomor 146 Tahun 2014 tentang Kurikulum 2013 PAUD yaitu dapat menceritakan kembali apa yang didengar dengan kosakata yang lebih dan melaksanakan perintah yang lebih kompleks sesuai dengan aturan yang disampaikan (Mendikbud RI. 2014, hlm. 30-31).
Pada dasarnya apabila cerita tersebut dapat tersampaikan dengan baik, maka kegiatan bercerita itu memiliki manfaat terutama bagi perkembangan bahasa anak. Sebagaimana Madyawati (2016, hlm. 167), menegaskan manfaat bercerita bagi anak diantaranya adalah sebagai berikut:

a) Membantu pembentukan pribadi dan moral anak. Cerita sangat efektif membentuk pribadi dan moral anak. Melalui cerita, anak dapat memahami nilai baik dan buruk yang berlaku pada masyarakat.

b) Menyalurkan kebutuhan imajinasi dan fantasi. Cerita dapat dijadikan sebagai media menyalurkan imajinasi dan fantasi anak. Pada saat menyimak cerita, imajinasi anak mulai dirangang. Imajinasi yang dibangun anak saat menyimak cerita memberikan pengaruh positif terhadap kemampuan anak dalam menyelesaikan masalah secara kreatif.

c) Memacu kemampuan verbal anak. Cerita dapat memacu kecerdasan linguistik anak. Cerita mendorong anak bukan saja senang menyimak cerita tetapi juga senang bercerita atau berbicara. Anak belajar tata cara berdialog dan bernarasi.

Maka berdasarkan teori tersebut, peneliti mengembangkan model interactive storytelling dibutuhkan oleh anak-anak sebagai sasaran proses bercerita tersebut di lapangan untuk memenuhi kebutuhan lapangan akan panduan bercerita yang interaktif dan bermanfaat bagi perkembangan bahasa anak utamanya keterampilan menyimak. Realisasi yang dilakukan melalui penelitian ini sudah terpenuhi untuk memfasilitasi kemampuan menyimak anak dengan upaya kegiatan bercerita, dan karenanya guru dapat mengaplikasikannya dengan memanfaatkan teknologi yang telah tersedia.

B. Design and Construction 
Pada tahap ini, peneliti merancang langkah-langkah bercerita yang terbagi menjadi tiga tahapan yaitu practicing divergent thinking sebagai planning, practicing revising clarity and correctness sebagai presenting, dan practicing new vocabulary usage sebagai evaluating.

a) Planning. Dalam tahap planning, guru membuka pembelajaran dengan ucapan salam dan berdo'a bersama. Setelah itu guru menyiapkan alat dan media yang dibutuhkan yakni perangkat beraplikasi android dan telah menginstal aplikasi cerita dari playstore. Kemudian guru mengatur formasi duduk anak dengan formasi melingkar untuk memulai melakukan apersepsi mengenai tema yang berkaitan dengan konten cerita. Kemudian guru menyampaikan kegiatan yang akan dilakukan dan memfasilitasi siswa untuk melakukan peregangan bersama agar anak lebih siap menerima pelajaran selanjutnya.

b) Presenting. Dalam tahap presenting guru membuka aplikasi android yang berisikan cerita anak yang telah dipilih, kemudian guru menuntun anak untuk menyebutkan judul cerita. Setelah itu guru mempersilahkan anak untuk menyimak cerita pada aplikasi android dan memantaunya sampai ceritanya selesai.

c) Evaluating. Pada tahap evaluating guru membimbing anak untuk menggunakan kosakata baru pada konteks yang berbeda. Kemudian untuk memfasilitasi daya simak dan bicara anak, guru memberi beberapa kegiatan interaktif diantaranya tanya jawab mengenai konten cerita, meminta anak untuk melanjutkan cerita, menginstruksikan anak untuk membuat roleplay berdasarkan cerita yang didapatkan secara beregu, dan memfasilitasi anak untuk bermain game yang tersedia pada aplikasi android. Untuk memberikan penguatan nilai moral dari cerita, guru memberikan reinforcement mengenai bagaimana menyelesaikan masalah pada kehidupan sehari-hari yang didapatkan dari isi cerita.

\section{Evaluation and Reflection}

Hasil perancangan awal produk ini telah diuji cobakan sekaligus sebagai validitas ekstemal guna mengetahui kelayakan dan kepraktisannya di lapangan. Sebagaimana menurut Pearl, 2014 (dalam Kumiawan, 2018, hlm. 131) bahwa "Validitas eksternal merupakan persoalan penelitian yang berkaitan dengan penanyaan, sejauh mana hasil suatu penelitian bisa digeneralisasikan pada populasi induk (asal sampel) di mana penelitian diambil atau validitas ekstemal berhubungan dengan generalisasi hasil penelitian". Maka dari itu, peneliti melaksanakan tahap uji coba hingga terbentuk produk yang diharapkan oleh bersama dan menghasilkan akhir produk yang optimal.

Pada uji coba tahap I, peneliti melakukan uji coba terbatas guna mengetahui keterpakaian awal sebelum guru mengaplikasikan rancangan tersebut. Setelah mengalami pertimbangan dan perbaikan oleh peneliti, pembimbing, serta guru terkait, maka tahap berikutnya dilakukan uji coba tahap I pada kelompok Bl di TK Perwari I. Dalam kegiatan ini, guru menjadi praktikan dan peneliti menjadi observer. Dalam pelaksanaan tahap evaluating, guru sempat mendapati kesulitan dalam mengondisikan anak-anak dikarenakan guru tidak membagi anak kedalam beberapa grup kecil. Akibatnya anakanak sempat tidak mau bergiliran untuk kedepan saat melakukan game cerita. Namun hal ini dapat ditangani dengan pengertian dan reward bagi anak yang hendak bersabar menunggu gilirannya. Sebagian besar anak-anak dapat menceritakan kembali apa yang telah didengar mengenai cerita tersebut dan dapat melaksanakan perintah saat guru memintanya. Capaian kemampuan menyimak anak kelompok B1 pada uji 
coba I adalah $67 \%$ berkembang sangat baik.

Setelah melalui refleksi dan revisi dari uji coba tahap I, langkah yang dilakukan adalah menguji kembali produk pada uji coba tahap II. Pada tahap ini, peneliti lebih mempersiapkan persiapan yang akan digunakan oleh guru sebagai praktikan. Pada prosesnya, guru dapat melaksanakan langkah-langkah interactive storytelling dan menggunakan sumber serta media elektronik yang telah disiapkan dengan baik dan benar. Hasilnya anak-anak dapat menyimak cerita dengan baik dan capaian kemampuan menyimak pada kelompok B2 adalah 91,5\% berkembang sangat baik. Maka dari hasil temuan-temuan tersebut, penelitian ini menguatkan teori menurut Schwab (dalam Cahyono: 2018) bahwa "Dunia tengah menghadapi transisi menuju revolusi industri $4.0 \mathrm{Hal}$ ini ditandai dengan tergabungnya dunia fisik, digital, dan biologishal tersebut menunjukkan bahwa akan ada perubahan ke arah lebih baik, bersamaan dengan berpadunya dunia fisik, digital dan biologis. Oleh sebab itu subjek pendidikan akan semakin berkualitas apabila objek pendidikannya berkualitas". Karenanya hasil pengembangan produk ini dapat memberikan manfaat untuk meningkatkan kemampuan menyimak anak usia dini.

\section{KESIMPULAN}

Berlandaskan hasil penelitian pengembangan model interactive storytelling berbasis aplikasi android untuk memfasilitasi keterampilan menyimak anak usia dini yang telah dilakukan, maka dapat diperoleh kesimpulan sebagai berikut ini:

A. Kebutuhan serta kekurangan yang belum tersedia untuk melaksanakan kegiatan bercerita yang interaktif dalam memfasilitasi kemampuan menyimak anak pada kelompok B taman kanak kanak adalah model bercerita berupa panduan bagi guru yang berimplikasikan teknologi pendidikan yang telah tersedia dalam aplikasi android. Belum adanya arahan dalam melaksanakan kegiatan bercerita berimplikasi aplikasi android mengakibatkan kurangnya kinerja guru dalam mengaplikasikan aplikasi yang telah tersedia dengan media yang sudah ada kedalam pembelajaran harian anak. Sedangkan minat awal anak pada kegiatan bercerita cukup antusias, namun dikarenakan kurangnya perencanaan dan persiapan yang baik berakibat kurangnnya kemampuan anak dalam menyimak cerita. Maka mengenai hal tersebut, pengembangan model interactive storytelling berbasis aplikasi android untuk memfasilitasi kemampuan menyimak anak dapat menjadi salah satu model pembelajaran untuk pengajaran guru kepada anak yang memanfaatkan teknologi pendidikan yang telah tersedia di era digital ini.

B. Rancangan model interactive storytelling berbasis aplikasi android untuk memfasilitasi kemampuan menyimak anak pada kelompok B taman kanak kanak ini terdiri dari tiga tahap. Tahap pertama adalah planning yang dimana guru mempersiapkan media/alat yang dibutuhkan dan mempersiapkan pengetahuan awal yang telah dimiliki anak dengan cara yang menyenangkan. Tahap selanjutnya adalah presenting, dimana guru menyajikan konten cerita sesuai tema berdasarkan aplikasi android. Tahap terakhir adalah evaluating, dimana guru memberikan tindak lanjut sebagai penguatan bagi anak terhadap cerita yang telah disimaknya melalui beberapa kegiatan seperti roleplay, dan game.

C. Ketercapaian anak dan guru pada pembelajaran uji coba model interactive storytelling berbasis 
aplikasi android untuk memfasilitasi kemampuan menyimak anak usia dini mendapatkan hasil capaian yang positif. Meskipun pada tahap I produk masih memiliki beberapa kekurangan, namun produk mencapai kelayakan yang optimal bagi kebutuhan di lapangan pada uji coba tahap II berdasarkan hasil refleksi dan revisi bersama praktisi.

D. Rancangan akhir produk model interactive storytelling berbasis aplikasi android untuk memfasilitasi kemampuan menyimak anak usia dini berupa skenario pembelajaran sebagai pegangan guru.

\section{DAFTAR PUSTAKA}

Cahyono, E. (2018, 27 Maret). "Revolusi Industri 4.0 dan Transformasi Organisasi Pemerintah". Sekretariat Kabinet RI, Tersedia https://setkab.go.id/revolusiindustri-4-0-dan-transformasiorganisasi-pemerintah/

Depdiknas. 2003. Undang-undang RI Nomor 20 Tahun 2003 Tentang Sistem Pendidikan Nasional. Jakarta: Depdiknas.

Gunawan, A. dkk (2019). Siapkah Kita Menghadapi Digital Transformation?. Pikiran Rakyat

Herrington, J. et al. (2007). Design-based research and doctoral students: Guidelines for preparing a dissertation proposal. Proceedings of World Conference on Educational Multimedia, Hypermedia and Telecommunications (pp. 40894097). Chesapeake, VA: AACE.

Nurzaman I., Gandana G. \& Lestari T. (2018). Interactive Storytelling Program untuk Meningkatkan Keterampilan Berbicara. Bandung: Universitas Pendidikan Indonesia.

Kemendikbud. 2014. Peraturan Menteri Pendidikan dan Kebudayaan Republik Indonesia Nomor 146 Tentang Kurikulum 2013 PAUD.
Jakarta: Kementrian Pendidikan dan Kebudayaan.

Lestari T., Mulyana E. H., Nurzaman I. \& Gandana G. (2019). Exploring the integrating potentials of role playing with youtube in building student's self confidence.Journal of Physics: conference series 1318 (1) 012048.

Madyawati, L. (2017). Strategi Pengembangan Bahasa pada Anak. Jakarta: Kencana.

Plomp, T. (2010). Educational Design Research: An Introduction: an Introduction. In T. Plomp \& N. Nieven, An Introductional to Educational Design Research (p. 9). Enschede, Netherland: SLO, Netherland Institute for Curriculum Development.

Sugiyono. (2017). Metode Penelitian Pendidikan. Bandung: Alfabeta.

Tarigan, H. G. (2014). Menyimak Sebagai Suatu Keterampilan Berbahasa. Yogyakarta: Graha Ilmu.

Universitas Pendidikan Indonesia (2011). Renstra UPI (2011-2015).

Bandung: UPI.

Van Den Akker, J. et al. (2006). Educational Design Research. USA and Canada: Routledge.

Yasbiati, Gandana G. \& Rahman T. (2019). Educative and digital base game (Power Point) game games as a stimulation method of discussion skill development early childhood. Journal of Physics: Conference Series 1318 